\title{
Reactivity of Zinc Finger Cysteines: Chemical Modifications Within Labile Zinc Fingers in Estrogen Receptor
}

\author{
Christian Atsriku, ${ }^{+}$Gary K. Scott, Christopher C. Benz, ${ }^{*}$ \\ and Michael A. Baldwin ${ }^{+}$ \\ Buck Institute for Age Research, Novato, California, USA
}

Estrogen receptor (ER, alpha isoform) is a $67 \mathrm{kDa}$ zinc finger transcription factor that plays a fundamental role in both normal reproductive gland development and breast carcinogenesis, and also represents a critical molecular target for breast cancer therapy. We are investigating the structural consequences of chemical exposures thought to modify essential zinc finger cysteine residues in human ER. The current study employs mass spectrometry to probe ER zinc finger structural changes induced by a redox-reactive vitamin K3 analog, menadione; a commonly used cysteine alkylator, iodoacetic acid; and a thiol alkylating fluorophore, monobromobimane. Although they are slower to react, the sterically bulkier reagents, monobromobimane and menadione, effectively alkylate the most susceptible ER zinc finger cysteine sulfhydryl groups. Menadione arylation results first in Michael addition of the hydroquinone followed by rapid oxidation to the corresponding quinone, evidenced by a $2 \mathrm{Da}$ mass loss per cysteine residue. Mass spectrometric analysis performed under MALDI conditions reveals both hydroquinone and quinone forms of arylated menadione, whereas only the quinone product is detectable under ESI conditions. Tandem mass spectrometry of a synthetic peptide encompassing the C-terminal half of the structurally more labile second zinc finger of ER ( $\mathrm{ZnF} 2 \mathrm{~B})$ demonstrates that the two nucleophilic thiols in ZnF2B (Cys-237, Cys-240) are not chemically equivalent in their reactivity to bromobimane or menadione, consistent with their unequal positioning near basic amino acids that affect thiol $\mathrm{pKa}$, thereby rendering Cys-240 more reactive than Cys-237. These findings demonstrate important differential susceptibility of ER zinc finger cysteine residues to thiol reactions. (J Am Soc Mass Spectrom 2005, 16, 2017-2026) (C) 2005 American Society for Mass Spectrometry

$\mathrm{T}$ The $67 \mathrm{kDa}$ human estrogen receptor (ER, alpha isoform) represents a critical transcription factor protein that mediates estrogen induced gene expression essential for normal reproductive gland development, the overexpression of which also drives the development of most human breast cancers and serves as the molecular target for all forms of breast cancer endocrine therapy $[1,2]$. Oxidative stress or chemical interference with either of the two $\mathrm{Cys}_{4}$-type zinc finger structures located within the ER DNA-binding domain (ER-DBD) may prevent its ability to directly bind DNA in a sequence-specific manner without impairing its ability to modulate gene expression by protein-protein interactions with other DNA-bound transcription factors $[3,4]$. Given the susceptibility of all zinc finger transcription factors to oxidative stress, recent studies

Published online October 24, 2005

Address reprint requests to Dr. M. A. Baldwin, Buck Institute for Age Research, 8001 Redwood Blvd., Novato, CA 94945, USA. E-mail: mikeab@itsa.ucsf.edu

* Also at the Comprehensive Cancer Center and Division of OncologyHematology, University of California, San Francisco, CA 94143-1770.

${ }^{+}$Also at the Mass Spectrometry Facility, Department of Pharmaceutical Chemistry, University of California, San Francisco, CA 94143-0446. have focused on the reactivity of zinc finger structures to various electrophilic compounds that selectively target nucleophilic residues, such as the zinc coordinating cysteine thiols found in the ER-DBD [4-7].

Evidence from computational and tertiary structural analysis by nuclear magnetic resonance (NMR) indicates that the second (C-terminal) zinc finger of ER (ZnF2) is loosely structured and, therefore, likely more labile [7-9], potentially explaining why the cysteine residues of ER ZnF2 appear more susceptible to oxidative stress and chemical attack than those in the more N-terminal zinc finger of ER [10]. While it has been proposed that chemical modification of ER zinc fingers may inhibit the growth of some ER expressing cancers by preventing ER dimerization and transactivation [5, 6], it has also been shown that exposure to electrophilic quinones such as those generated during estrogen metabolism can induce tumorigenesis via their redox cycling or direct structural attack of nucleic acids and proteins, including ER [11-15]. Of particular interest, protein-quinone conjugates can theoretically become molecular platforms for continued intracellular quinonehydroquinone cycling, local generation of reactive oxy- 


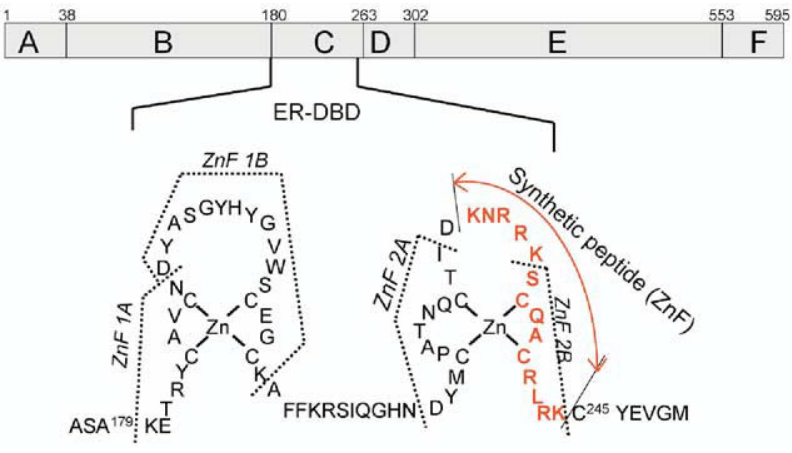

Figure 1. ER-DBD showing the N-terminal and C-terminal zinc fingers. Double protease digestion with endoproteinase Lys- $C$ and Asp-N yields four diagnostic zinc finger peptides: $\mathrm{ZnF1A}, 1 \mathrm{~B}, 2 \mathrm{~A}$, and $2 \mathrm{~B}$. The synthetic peptide $\mathrm{ZnF}$ corresponds to residues 231244.

gen species (ROS), and chronic propagation of oxidative damage to surrounding macromolecules.

The vitamin $\mathrm{K}$ analog menadione (K3), capable of both redox cycling and arylating nucleophilic substrates by Michael addition, has been extensively studied as a model stress inducing quinone [15]. In addition to activating intracellular oxidant stress pathways, mass spectrometry (MS) analysis has recently revealed that brief exposure to $\mathrm{K} 3$ can result in arylation of the singular cysteine residue (Cys110) within histone H3.3/H3 [16]. Earlier studies had shown that brief treatment of ER-expressing breast cancer cells in culture with $\mathrm{K} 3$ also results in irreversible functional loss of ER-DNA binding [3], presumably due to the Michael addition of either the quinone or hydroquinone form of $\mathrm{K} 3$ to one or more nucleophilic groups within the ER-DBD [17, 18]. However, analytical and structural studies of chemical modifications within the ER-DBD remain challenging, given the much lower abundance of endogenous ER relative to proteins like histone $\mathrm{H} 3.3 / \mathrm{H} 3$, even when ER is markedly overexpressed in human breast cancer cells. Biochemical methods such as the zinc ejection assay have been used to indirectly assess the lability of ER zinc fingers to electrophilic attack [5]; but we believe that direct MS assessment will ultimately be required to measure and precisely identify chemical modifications within the DBD of endogenously expressed ER.

As an important step towards this aim, we have sought to develop and optimize a mass spectrometry based technique to fingerprint in vitro covalent changes occurring in the zinc fingers of human ER protein. The current study employed human recombinant ER protein and synthetic ER zinc finger peptides to develop MS and tandem MS (MS/MS) methods capable of probing the ER-DBD for structural changes induced by various thiol-reactive agents. To specifically assess arylation products formed by quinones like K3, we extended our previously described protocol involving double enzymatic digestion of ER (Figure 1), followed by liquid chromatography-electrospray ionization (LCESI) MS [19]. As shown in Table 1, in addition to K3, other thiol-reactive agents used to treat ER protein or synthetic peptides included iodoacetic acid (IAA) and monobromobimane (BrB). IAA is typical of several standard alkylating reagents widely used in protein chemistry and MS studies to protect cysteine thiols against oxidation or uncontrolled alkylation, as seen during polyacrylamide gel electrophoresis [20]. The fluorescent agent $\mathrm{BrB}$ is less well known in MS studies; similar in size to K3, its steric bulkiness has been used to map drug binding sites in proteins [21]. While $\mathrm{BrB}$ fluorescence is a valuable property for monitoring overall thiol oxidation status in proteins, the existence of four cysteine residues outside the ER-DBD (which itself contains nine cysteines, as shown in Figure 1), renders total $\mathrm{BrB}$ fluorescence noninformative with respect to ER-DBD thiol status. To probe for position-specific cysteine reactivity within an ER-DBD zinc finger, we

Table 1. Chemical structures of alkylating/arylating reagents used in this study

\begin{tabular}{cccc}
\hline Reagent & Structure & Nominal mass \\
change per Cys \\
\hline \hline lodoacetic acid (IAA)
\end{tabular}

Menadione (k3)<smiles>CC1=CC(=O)c2ccccc2C1=O</smiles><smiles>[R]Sc1c(C)c(O)c2ccccc2c1O</smiles> 


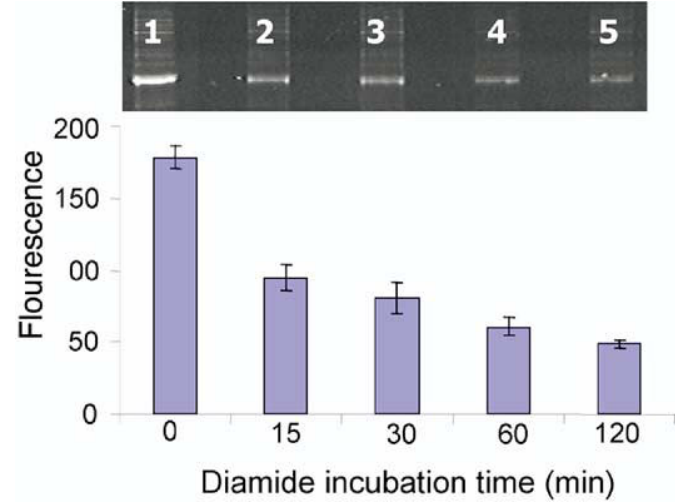

Figure 2. 1D gel showing fluorescent bands of recombinant ER visualized under UV light $(365 \mathrm{~nm})$ produced by titration of ER $(10 \mathrm{pmol})$ with the thiol-specific oxidant, diamide, followed by labeling with BrB and densitometry. Lane 1, no diamide; lanes 2 to 5 , diamide treatment for $15,30,60$, and $120 \mathrm{~min}$ respectively.

used MS/MS analysis of a synthetic peptide encompassing the C-terminal half of ER ZnF2 (Figure 1).

\section{Materials and Methods}

\section{Materials}

2-Methyl 1,4-naphthoquinone (K3), 3-bromomethyl2,5,6-trimethyl-pyrazolo[1,2-a]pyrazole-1,7-dione (BrB), iodoacetic acid (IAA), dithiothreitol (DTT), 2,4-dihydroxybenzoic acid (DHB), $\alpha$-cyano-4-hydroxy cinnamic acid (HCCA), formic acid, and trifluoroacetic acid (TFA) were purchased from Sigma-Aldrich (St. Louis, $\mathrm{MO})$. Acetonitrile, HPLC-grade, was acquired from Fisher Scientific (Pittsburgh, PA). Two versions of the synthetic zinc finger peptide (KNRRKSCQACRLRK) prepared by AnaSpec Inc. (San Jose, CA) with free cysteines $(\mathrm{ZnF})$ and with cysteines blocked by acetamidomethyl groups $\left(\mathrm{ZnF} \cdot \mathrm{acm}_{2}\right)$, respectively, were dissolved in water at $5 \mathrm{mg} / \mathrm{ml}$ and stored at $-20^{\circ} \mathrm{C}$ for subsequent use. The recombinant $\alpha$ isoform of ER (67 kDa) was obtained from Pan Vera (Madison, WI).

\section{Monitoring ER Oxidation Status by BrB Labeling}

Briefly, the strategy involved titration of ER (14 pmol) with the thiol-oxidant, diamide $\left[\left(\mathrm{CH}_{3}\right)_{2} \mathrm{NCON}=\mathrm{NCON}\left(\mathrm{CH}_{3}\right)_{2}\right]$ $(100 \mu \mathrm{M})$, as a function of time $(15-120 \mathrm{~min})$ to induce cysteine-disulfide oxidation at room-temperature. This was followed by labeling of any remaining free cysteine thiols with the fluorescentagent ${ }^{\circ} \mathrm{BrB}^{9}\left(3^{9} \mathrm{mM}\right)$ in ${ }^{9}$ the dark ${ }^{\circ} t^{\circ} 40^{\circ} \mathrm{C}$ for $60 \mathrm{~min}$. The labeled protein was then heated with Laemmli sample buffer $\left(95^{\circ} \mathrm{C} / 5 \mathrm{~min}\right)$, loaded onto a gel (SDS-PAGE) and separated at $200 \mathrm{~V}$ for $45 \mathrm{~min}$. The gel was subsequently fixed and washed in 10\% acetic acid/40\% methanol (vol/ vol), followed by visualization and densitometric analysis of fluorescent ${ }^{\circ}$ bands $^{\circ}$ on $^{\circ}$ the ${ }^{\circ}$ gel $^{\circ}$ (Figure $\left.{ }^{\circ} 2\right)^{\circ}{ }^{\circ}$ The $^{\circ}$ decrease ${ }^{\circ}$ in fluorescence intensity was attributed to cysteine-disulfide formation (oxidation) before $\mathrm{BrB}$ labeling of the remaining free thiol groups.

\section{Alkylation Reactions and Kinetic Studies}

A group of alkylation reaction experiments was preceded by complete reduction of all cysteine-disulfides in the synthetic peptide by the addition of $20 \mu \mathrm{l}$ DTT (10 $\mathrm{mM})$ to $80 \mu \mathrm{l}$ of the peptide solution $(100 \mathrm{pmol} / \mu \mathrm{l})$ and heating for $60 \mathrm{~min}$ at $40{ }^{\circ} \mathrm{C}$. Aliquots $(5 \mu \mathrm{l})$ of the peptide solution $(78 \mathrm{pmol} / \mu \mathrm{l})$ were transferred into separate siliconized tubes and diluted to $40 \mu \mathrm{l}$ with either formic acid $(0.1 \% \mathrm{vol} / \mathrm{vol})$, distilled water, or ammonium bicarbonate $(25 \mathrm{mM})$ at $\mathrm{pH} 2.8,7.4$ or 9.0 , respectively. Excess alkylating agent was added to a final concentration of $5 \mathrm{mM}$ and the reaction mixture was incubated at $37^{\circ} \mathrm{C}$ in the dark. Aliquots $(4 \mu \mathrm{l})$ of the reaction mixture were taken at specific time intervals between 0 and $120 \mathrm{~min}$, diluted tenfold in $0.1 \%$ formic acid to bring the peptide concentration to $\sim 10 \mathrm{pmol} / \mu \mathrm{l}$, and immediately mixed (1:1 vol/vol) with the MALDI matrix (DHB) and analyzed by MALDI-TOF. The rate of each reaction was monitored by following the rate of disappearance of the unconjugated peptide, assuming that MALDI peak intensities were approximately proportional to concentration. A pseudo-first-order rate constant $\left(k, \mathrm{~s}^{-1}\right)$ for reaction with each of the selected reagents was determined experimentally from the slope of a plot of natural logarithm (ln) of the percentage of unreacted peptide versus incubation time.

\section{In Vitro Chemical Modification of Recombinant ER}

Alkylation experiments involving ER with either IAA, $\mathrm{BrB}$, or $\mathrm{K} 3$ were carried out according to our previously described $^{\circ}$ double $^{\circ}$ protease $^{\circ}$ digestion protocol ${ }^{\circ}[19] .{ }^{\circ} \mathrm{A}$ solution ${ }^{\circ}$ of $^{\circ} \mathrm{ER}^{\circ}(5 \mathrm{pmol})$ was treated with each of the respective alkylating/arylating agents to a final concentration of $4 \mathrm{mM}$ in separate tubes and incubated at $37^{\circ} \mathrm{C}$ in the dark for $90 \mathrm{~min}$. Incubation reactions of ER with K3 were performed in slightly acidified medium with acetic acid $(0.1 \% \mathrm{vol} / \mathrm{vol})$. The reaction mixture was then diluted tenfold with ammonium bicarbonate $(\mathrm{pH}$ $8,25 \mathrm{mM}$ ), followed by a $3 \mathrm{~h}$ digestion with endoproteinase Lys-C (360 ng) from Lysobacter enzymogenes (Roche Diagnostics, Indianapolis, IN). The second enzyme, endoproteinase Asp-N (140 ng), derived from Pseudomonas fragi (Roche) was added and digestion allowed to continue for $3 \mathrm{~h}$ at $37^{\circ} \mathrm{C}$ in the dark. The resulting peptide mixture was desalted using a C-18 ZipTip with a $0.6 \mu \mathrm{l}$ bed volume (Millipore, Bedford, MA). Peptides were eluted with $25 \mu \mathrm{l}$ 60:40 vol/vol acetonitrile $/ 0.1 \% \mathrm{vol} / \mathrm{vol}$ formic acid, concentrated by Speedvac to near dryness and reconstituted in $10 \mu \mathrm{l}$ formic acid $(0.1 \% \mathrm{vol} / \mathrm{vol})$ for subsequent analysis by MALDI-TOF and LC-ESI-MS/MS.

\section{MALDI-TOF Analysis}

MALDI-TOF was carried out using a Voyager-DE STR instrument (Applied Biosystems, Framingham, 
MA) equipped with a $\mathrm{N}_{2}$ laser (337 nm). Equal volumes $(1: 1 \mathrm{vol} / \mathrm{vol})$ of the peptide reaction mixture containing the alkylation reagent in formic acid $(0.1 \%$ $\mathrm{vol} / \mathrm{vol}$ ), distilled water, or ammonium bicarbonate were mixed with either DHB or HCCA matrix and manually spotted onto the MALDI target plate. Mass spectra were recorded in positive ion reflector mode, 100 shots being accumulated for each spectrum. The instrument was calibrated using an external apomyoglobin standard. Spectra were smoothed by applying a Gaussian function and the baseline was corrected. Semiquantitation of peptides (unalkylated and alkylated adducts) was achieved using the manufacturer's software for integration of the monoisotopic ( $\mathrm{mi}$ ) peaks (Applied Biosystems, Foster City, CA). To determine relative abundances, the peak height of the unconjugated peptide was expressed as a percentage of the sum of the peak heights of the unconjugated and conjugated peptide species in each spectrum. Peptide maps of ER were generated for double protease digestions (Lys-C and Asp-N) of the untreated and treated (IAA, BrB, or K3) protein. MALDI-TOF spectra generated using 1:1 $\mathrm{vol} / \mathrm{vol}$ mixture of the digest and HCCA matrix were internally calibrated using autolysis peaks of endoproteinase Lys-C. Using the MS-FIT search engine in ProteinProspector v 4.0.5 (University of California, San Francisco), $m / z$ values for diagnostic peptides in the control and treated samples of ER were compared to identify modified cysteine residues.

\section{LC-ESI-MS/MS Analysis}

LC-ESI-MS/MS analysis was carried using a QSTAR Pulsar mass spectrometer (MDS Sciex, Concord, Ontario, Canada) operated in the positive-ion mode with a nano-electrospray needle voltage of $2300 \mathrm{~V}$. Samples $(2 \mu \mathrm{l})$ were injected using a Famos autosampler (LC Packings) and separation achieved using a $75 \mu \mathrm{m}$ $\times 150 \mathrm{~mm}$ PepMap reversed-phase column (5 $\mu \mathrm{m}$ particle size) (LC Packings, Sunnyvale, CA). Elution of peptides from the column was carried out with a binary solvent system: solvent A $(0.05 \%$ formic acid in $98 \% \mathrm{H}_{2} \mathrm{O} / 2 \%$ acetonitrile) and solvent $\mathrm{B}(0.05 \%$ formic acid in $2 \% \mathrm{H}_{2} \mathrm{O} / 98 \%$ acetonitrile) at a flow rate of $300 \mathrm{nl} / \mathrm{min}$. The gradient was $2 \%$ solvent $\mathrm{B}$ from $0-5 \mathrm{~min}$, followed by $2-70 \%$ solvent B from $5-55$ min. MS and tandem MS data were recorded continuously based on a 4-s cycle time. Within each cycle, MS data were accumulated for $1 \mathrm{~s}$, followed by $3 \mathrm{~s}$ MS/MS acquisitions. Nitrogen gas was used for collision dissociation and collision energy automatically ramped with respect to $m / z$ value of selected ion. Precursor ion selection for CID was based on the creation of an inclusion list of anticipated precursor ions.

\section{Results}

\section{Fluorescence Detection of ER Thiol Status}

The fluorescent property of thiol-bound BrB allows its arylation of ER to be monitored by protein electrophoresis and ${ }^{\circ}$ fluorimetry, ${ }^{\circ}{ }^{\circ}$ shown $^{\circ}$ in ${ }^{\circ}$ Pigure 2 2. ${ }^{\circ}$ Recombinant ER protein was first oxidized with diamide for 0-120 min and then exposed to excess BrB to quench the reaction and allow for $\mathrm{BrB}$ reaction with remaining unreacted ER cysteine residues. After separation by SDS-PAGE and fluorescence visualization, the BrB fluorescence intensity of the intact $67 \mathrm{kDa}$ ER protein band measured by densitometry showed the expected progressive loss in ER fluorescence with increasing diamide preoxidation time, indicating a proportional loss in ER free thiols. However, the residual fluorescence and plateau shape of the ER fluorescence loss by 120 min, despite treatment with diamide at a dose known to completely ${ }^{\circ}$ liminate ERDNA binding [3], suggests that BrB may either alkylate other ER nucleophilic residues not susceptible to diamide or otherwise not serve as a specific indicator of ER thiol oxidation status. Thus, more precise MS techniques were used to monitor alkylation of ER by BrB as well as by two other known thiol reactants, IAA and K3, not readily monitored by fluorescence. These chemical reactions were first studied by using a synthetic peptide substrate, $\mathrm{ZnF}$, representing the C-terminal half of the second ER zinc finger, and then confirmed by using recombinant ER protein as substrate $^{\circ}\left(\right.$ Figure $\left.^{\circ} 1\right)$.

\section{MS Analysis of ER Zinc Finger Peptide}

As $\mathrm{ZnF}$ contains two cysteine residues, three possible molecular ions were anticipated for each reaction, representing unreacted (0), singly-conjugated (1), and doubly-conjugated (2) peptides. Representative MALDI-TOF spectra generated from $1 \mathrm{~h}$ incubations of $\mathrm{ZnF}^{\circ}$ with $^{\circ}$ each $^{\circ}$ reagent $^{\circ}$ are $^{\circ}$ shown $^{\circ}$ in $^{\circ}$ Figure $^{\circ} 3,{ }^{\circ}$ all reactions ${ }^{\circ}$ being ${ }^{\circ}$ carried $^{\circ}$ out $^{\circ}$ at ${ }^{\circ} \mathrm{pH}^{\circ} 7.4^{\circ}$ and ${ }^{\circ} 37^{\circ} \mathrm{C}^{\circ}$. Figure $3 \mathrm{a}^{\circ}$ illustrates ${ }^{\circ}$ the ${ }^{\circ} \mathrm{ZnF}^{\circ}$ reaction ${ }^{\circ}$ products $^{\circ}$ formed ${ }^{\circ}$ with IAA. As anticipated, the doubly-alkylated species gave a protonated molecular ion at $\mathrm{m} / \mathrm{z} 1863$, which constituted the most intense peak. The mono-alkylated peptide ion $(m / z 1805)$ represented the second most abundant ion, and the unreacted peptide ion $(\mathrm{m} / \mathrm{z} 1747)$ was not readily detectable. The presence of a weak peak at $\mathrm{m} / \mathrm{z} 1921$ suggested formation of triply (3) alkylated adducts of IAA, possibly resulting from additional IAA reaction with an $\alpha$-amino group. Since $\mathrm{ZnF}$ contains three lysine (K) residues (KNRRKSCQACRLRK), each possessing a $\varepsilon$-amino group slightly more basic (pKa $10.5)^{\circ}$ than $^{\circ}$ their ${ }^{\circ} \alpha$-amino ${ }^{\circ}$ group $^{\circ}\left(\mathrm{pKa}^{\circ} 9.1\right)^{\circ}[22]^{\circ},{ }^{\circ}$ we investigated whether these moieties might be susceptible to alkylation by IAA at increased $\mathrm{pH}$. As shown in

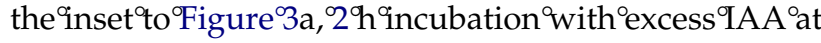
$\mathrm{pH} 10$ produced ions at $\mathrm{m} / \mathrm{z}$ 1921, 1979, 2037, and 2095, consistent with (3), (4), (5), and (6) peptide adducts, by 


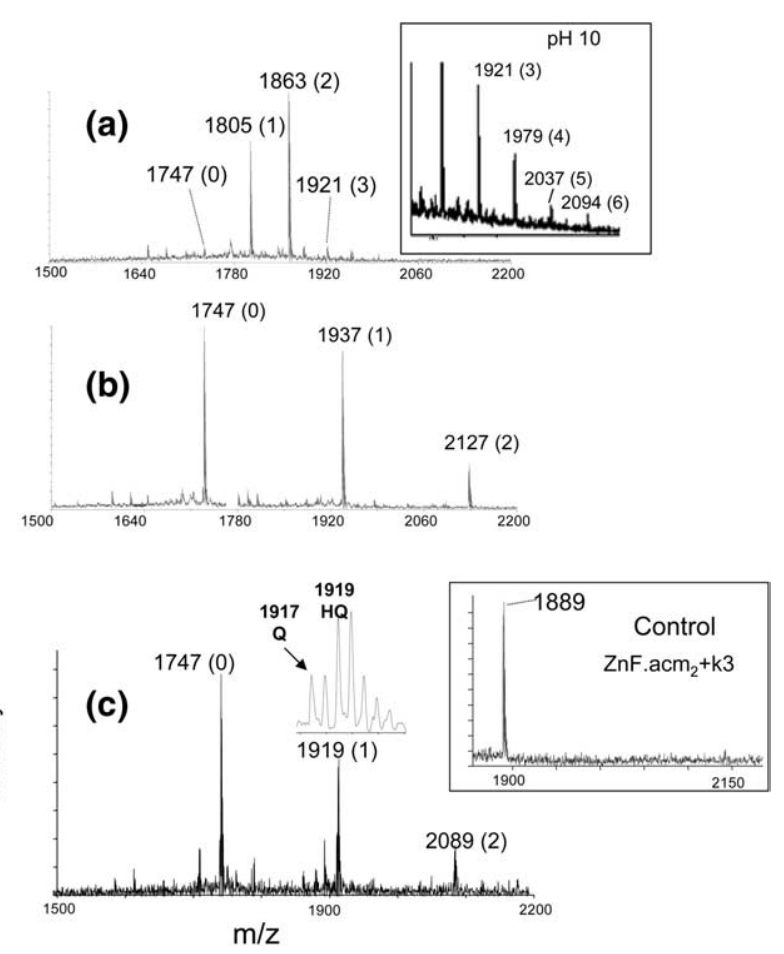

Figure 3. Representative MALDI-TOF spectra generated from $1 \mathrm{~h}$ incubation $\left(\mathrm{pH} 7.4,37^{\circ} \mathrm{C}\right.$ ) of synthetic peptide $\mathrm{ZnF}$ with: (a) IAA, (b) BrB, and (c) K3. Each reaction gave mono (1) and doubly (2) ${ }^{\circ}$ alkylated/arylated ${ }^{\circ}$ peptide ${ }^{\circ}$ conjugates. ${ }^{\circ A} A^{\circ}{ }^{\circ}{ }^{\circ}{ }^{\circ} H^{\circ}{ }^{\circ},{ }^{\circ}\left(\right.$ Figure $^{\circ}$ a inset) gave additional adduct ions for triple (3), quadruple (4), pentuple (5), and hexatuple (6) conjugates. Incubation of K3 with $\mathrm{ZnF} \cdot \mathrm{acm} 2$ with acetamidomethyl-protected thiols gave no arylation ((c) inset).

comparison with the (3) adducts formed at $\mathrm{pH} 7.4$. Thus, under alkaline conditions IAA not only alkylates all free thiols in $\mathrm{ZnF}$ but also its lysine $\varepsilon$-amino groups.

By comparison with these highly efficient IAA alkylations of $\mathrm{ZnF}$ thiol and amino groups, $\mathrm{BrB}$ and $\mathrm{K} 3$ arylation of $\mathrm{ZnF}$ were much less effective at $\mathrm{pH} 7.4$ and $37^{\infty} \mathrm{C}$. ${ }^{\circ}$ igure ${ }^{\circ} 3 \mathrm{~b}^{\circ}$ shows ${ }^{\circ}$ that after $\mathrm{BrB}$ treatment, unreacted peptide (0) at $\mathrm{m} / \mathrm{z} 1747$ remained the major component along with a slightly lower abundance signal from the mono-alkylated peptide (1) at $\mathrm{m} / \mathrm{z}$ 1937; only $\mathrm{a}^{\circ}$ minor $^{\circ}$ proportion ${ }^{\circ}$ of $^{\circ}$ doubly-alkylated peptide conjugate $^{\circ}(2)^{\circ}$ at $^{\circ} \mathrm{m} / z \quad 2127^{\circ}$ was $^{\circ}$ detectable. ${ }^{\circ}$ Figure $3 \mathrm{c}$ shows ${ }^{\circ}$ that ${ }^{\circ}$ after ${ }^{\circ} \mathrm{K} 3$ treatment, similar abundance profiles were noted as for BrB treatment. Furthermore, the K3 MALDI-TOF spectra revealed that instead of detecting only K3 hydroquinone arylation products (each adding $172 \mathrm{Da}$ to the $\mathrm{ZnF}$ molecular mass, as indicated in $^{\circ}$ Table $^{\circ} 1$ ), ${ }^{\circ}$ the ${ }^{\circ}$ isotopic $^{\circ}$ envelopes $^{\circ}$ for ${ }^{\circ}$ mono- $^{\circ}$ and doubly-arylated conjugates indicated the presence of both $^{\circ} \mathrm{K} 3^{\circ}$ quinone ${ }^{\circ}\left(\mathrm{Q}^{\circ} \mathrm{m} / \mathrm{z} 1917\right)^{\circ}$ and $^{\circ}$ hydroquinone ${ }^{\circ}(\mathrm{HQ}$, $\mathrm{m} / z$ 1919) adducts, ${ }^{\circ}{ }^{\circ}$ illustrated in ${ }^{\circ}$ the Figure $3 \mathrm{c}^{\circ}$ expansion ${ }^{\circ}$ panel for the mono adduct signal. Multiple reactions between $\mathrm{K} 3$ and $\mathrm{ZnF}$ resulted in variable spectral ratios of $\mathrm{Q}: \mathrm{HQ}$, with $\mathrm{Q}$ being the more prevalent species, particularly when analyzed by LC-ESI-MS, suggesting that oxidation of the arylated $\mathrm{HQ}$ to its $\mathrm{Q}^{\circ}$

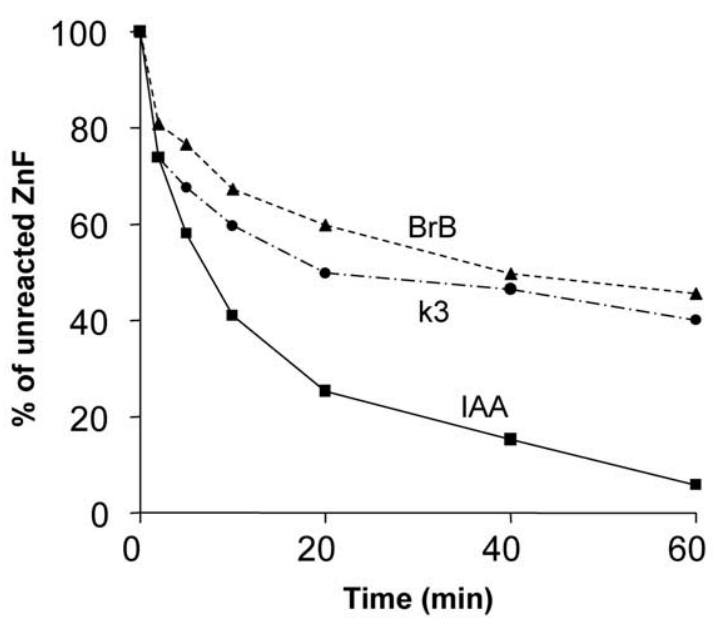

Figure 4. Time course profiles for disappearance of unreacted $\mathrm{ZnF}$ in reactions with $\mathrm{IAA}, \mathrm{BrB}$, and $\mathrm{K} 3$. The unreacted peptide ion peak heights (monoisotopic) are expressed as a percentage of the total peak heights for the unreacted, mono, and doublyconjugated peptide ions in each MALDI-TOF spectrum.

form ${ }^{9}$ as $^{\circ}$ occurring during the sample separation phase of the analysis. To confirm the thiol specificity of $\mathrm{ZnF}$ arylation by $\mathrm{K} 3$, an alternative form of the synthetic $\mathrm{ZnF}$ peptide was used, $\mathrm{ZnF} \cdot \mathrm{acm}_{2}$, the same as $\mathrm{ZnF}$ except that the two cysteine thiols are blocked by acetamidomethyl $(\mathrm{acm})$ groups. Even when this $\mathrm{ZnF} \cdot \mathrm{acm}_{2}$ peptide was incubated with $\mathrm{K} 3$ for $3 \mathrm{~h}$ at $\mathrm{pH} 7.4\left(37^{\circ} \mathrm{C}\right)$, no arylation products were observed, as demonstrated by the ${ }^{\circ}$ unreacted $^{\circ}$ peak $^{\circ}(\mathrm{m} / \mathrm{z} 1889)^{\circ}$ in $^{\circ}$ the ${ }^{\circ}$ Figure $^{\circ} 3 \mathrm{c}^{\circ}$ insert. The conclusion that $\mathrm{K} 3$ arylation of $\mathrm{ZnF}$ occurs only on free cysteines at $\mathrm{pH} 7.4$ was further confirmed by tandem MS mass spectrometry (see below). However, as seen with IAA under alkaline conditions, a low abundance $\mathrm{K} 3$ peak likely representing arylation of the $\mathrm{N}$-terminal $\alpha$-amino group was detected (data not shown).

The observed degree of reactivity for the various $\mathrm{ZnF}$ alkylating reagents was IAA $\gg \mathrm{BrB} \cong{ }^{\circ} \mathrm{K} 3{ }^{\circ}$ graphically demonstrated ${ }^{\circ}$ by $^{\circ}$ the ${ }^{\circ}$ Figure $^{\circ} 4$ time course profiles showing disappearance of unreacted peptide measured by MALDI-TOF. By carrying out the reactions at different $\mathrm{pH}$, it was also observed that nucleophilic attack by IAA and BrB occurred more rapidly at higher $\mathrm{pH}$, consistent with their dependence on thiolate anions. Assuming pseudo first-order reactions (suggested by the linearity $^{\circ}{ }^{\circ}$ ssemilog $^{\circ}$ plots ${ }^{\circ}$ of Figure $4^{\circ}$ data) ${ }^{\circ}$ and ${ }^{\circ}$ mono adduct formation on $\mathrm{ZnF}$, approximate rate constants were ${ }^{\circ}$ calculated ${ }^{\circ}$ for $^{\circ}$ each $^{\circ}$ reagent $^{\circ}$ as $^{\circ}$ shown $^{\circ}$ in $^{\circ}$ Table $^{\circ} 2$.

Table 2. Pseudo first order rate constants $\left(\mathrm{min}^{-1}\right)$ for the rate of disappearance of unreacted peptide upon incubation with excess reagent at $37^{\circ} \mathrm{C}$

\begin{tabular}{cccc}
\hline $\mathrm{pH}$ & IAA & $\mathrm{BrB}$ & K3 \\
\hline \hline 2.8 & $0.4 \times 10^{-2}$ & $0.5 \times 10^{-2}$ & $5.5 \times 10^{-2}$ \\
7.4 & $7.2 \times 10^{-2}$ & $2.0 \times 10^{-2}$ & $2.2 \times 10^{-2}$ \\
9.0 & $21.9 \times 10^{-2}$ & $3.4 \times 10^{-2}$ & $0.1 \times 10^{-2}$ \\
\hline
\end{tabular}




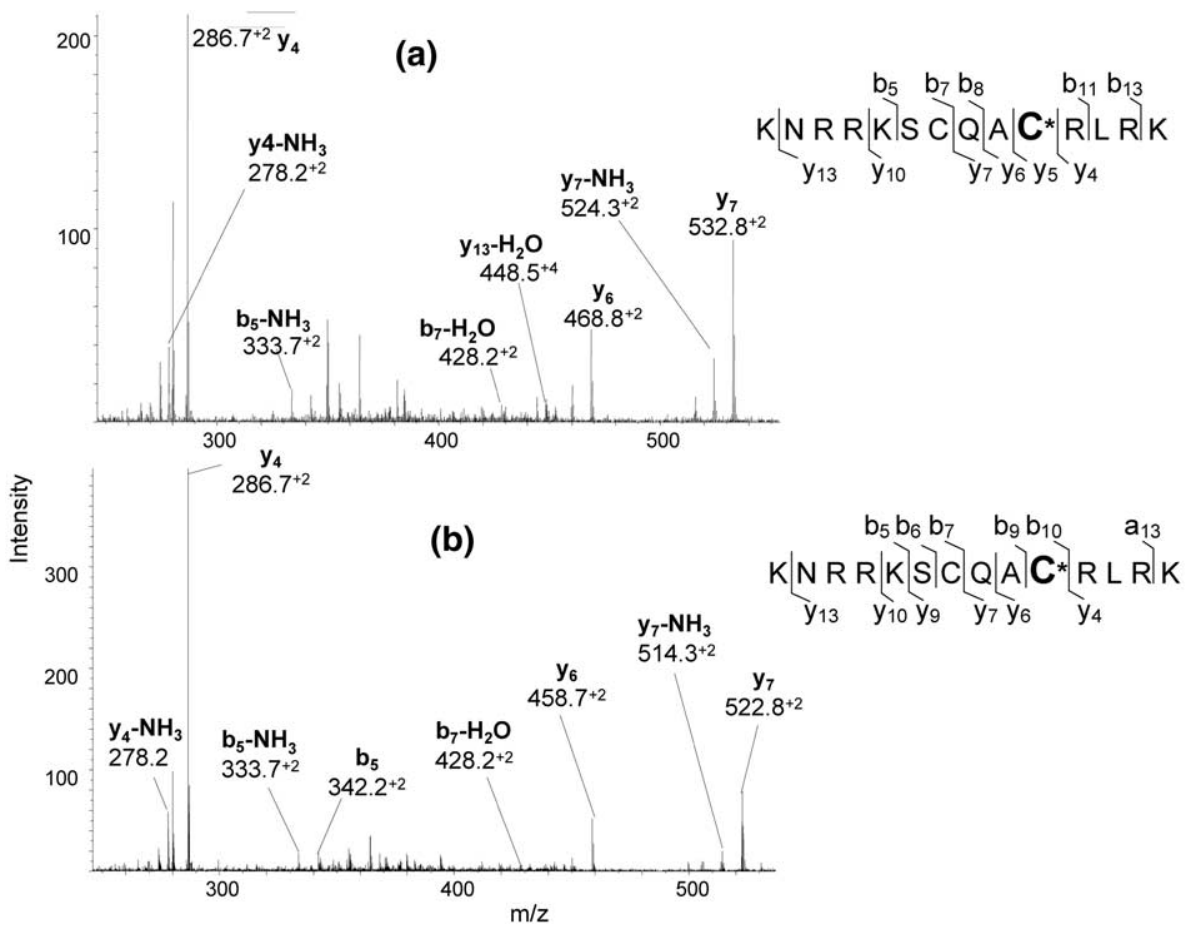

Figure 5. Examples of LC-ESI-MS/MS spectra of mono-arylated synthetic peptide ZnF. (a) Monosubstituted by BrB: spectrum from precursor ion $m / z 388.2(+5)$. (b) Mono-substituted by K3: spectrum from precursor ion $384.2(+5)$. The schematic cleavage diagrams combine fragmentations from all charge states studied by LC-ESI-MS/MS and from MALDI-TOF/TOF spectra.

Apparent from this table are the near 50 -fold more rapid IAA reaction rate at $\mathrm{pH} 9$ relative to $\mathrm{pH} 2.8$ and the 7 -fold more rapid rate for $\mathrm{BrB}$ at alkaline $\mathrm{pH}$, in contrast to the K3 Michael addition reaction which proceeded 50 -fold slower at alkaline $\mathrm{pH}$.

Although IAA rapidly reacts with both cysteine residues in $\mathrm{ZnF}$, the major products resulting from $\mathrm{BrB}$ or K3 reactions were single adducts. Since cysteine residues might be differentially reactive, the $\mathrm{BrB}$ and $\mathrm{K} 3$ adducted $\mathrm{ZnF}$ structures were probed by tandem MS. Figure $^{\circ} 5^{\circ}$ shows $^{\circ}$ LC-ESI-MS MS $^{\circ}$ spectra $^{\circ}$ from $^{\circ}$ the $^{\circ} 5+$ charge ${ }^{\circ}$ states $^{\circ}$ of $^{\circ}$ the $^{\circ} \mathrm{BrB}^{\circ}$ (Figure ${ }^{\circ} 5$ a, ${ }^{\circ}$ precursor ${ }^{\circ}$ ion $^{\circ} \mathrm{m} / \mathrm{z}$

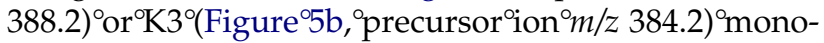
alkylated ${ }^{\circ} \mathrm{ZnF} .{ }^{\circ}$ Analogous ${ }^{\circ}$ spectra ${ }^{\circ}$ recorded $^{\circ}$ for ${ }^{\circ}$ other charge states (not shown) were comparable but revealed some additional fragment ions. Confirmatory MALDI-TOF/TOF tandem MS were also obtained (data not shown). Since $\mathrm{BrB}$ and $\mathrm{K} 3$ reactions could be specific to Cys-237, Cys-240, a mixture of both thiols, and also a fraction of $\mathrm{N}$-terminal $\alpha$-amino groups, a table of calculated fragment masses was constructed to account for each possible structure and to interrogate the MS/MS spectra for the presence of these peaks. Table ${ }^{\circ}{ }^{\circ}$ includes ${ }^{\circ}$ all ${ }^{\circ}$ fragment ${ }^{\circ}$ ions ${ }^{\circ}$ observed ${ }^{\circ}$ by ${ }^{\circ}$ LC-ESIMS/MS, including those with various charge states; all sequence fragment ions ( $b$ and $y$ ) detected following $\mathrm{BrB}$ and $\mathrm{K} 3$ reactions are shown in the fragmentation schemes $^{\circ}$ in $^{\circ}$ Figure $^{\circ} 5 a^{\circ}$ and $^{\circ} b .{ }^{\circ}$ The $^{\circ}$ masses $^{\circ}$ of ${ }^{\circ}$ fragment ions that were formed by cleavage between the two cysteine residues, such as the abundant ions $\mathrm{y}_{6}$ and $\mathrm{y}_{7}$, allowed the location of the $\mathrm{BrB}$ and $\mathrm{K} 3$ modifications to be determined unambiguously. No fragment ions were observed that could be unique to modification of the $\mathrm{N}$-terminus or Cys-237, whereas strong ions were found that were unique to modifications involving Cys-240. Thus, the tandem MS data excluded the possibility of any $\mathrm{N}$-terminal reactions by either $\mathrm{BrB}$ or $\mathrm{K} 3$, and demonstrated that mono-adduction by both reagents targeted Cys-240 to the exclusion of Cys-237.

\section{MS Analysis of Full-Length (67 kDa) ER}

Treatment and MS analysis of recombinant ER protein followed a previously described double enzyme (Lys-C and $\left.^{\circ} \mathrm{Asp}-\mathrm{N}\right)^{\circ}$ digestion protocol $\left.^{\circ} 19\right]^{\circ}{ }^{\circ}$ designed to separate components ${ }^{\circ}$ of $^{\circ}$ each $^{\circ} \mathrm{ER}^{\circ}{ }^{\circ}$ zinc $^{\circ}$ finger, ${ }^{\circ}$ as ${ }^{\circ}$ shown ${ }^{\circ}$ in ${ }^{\circ}$ Figure 1..$^{\circ}$ Figure $^{\circ} 6^{\circ}$ shows $^{\circ}$ the ${ }^{\circ}$ resulting ${ }^{\circ}$ MALDI-TOF ${ }^{\circ}$ peptide mass $^{\circ}$ fingerprints ${ }^{\circ}$ from $^{\circ}$ untreated $^{\circ}\left(\right.$ Figure $^{\circ}$ 6a), ${ }^{\circ}$ IAA treated $^{\circ}\left(\right.$ Figure $\left.^{\circ} 6 \mathrm{~b}\right),{ }^{\circ} \mathrm{BrB}^{\circ}$ treated ${ }^{\circ}\left(\right.$ Figure $\left.^{\circ} 6 \mathrm{c}\right),{ }^{\circ}$ and $^{\circ} \mathrm{K} 3$ treated $^{\circ}\left(\text { Figure }^{\circ} 6 \mathrm{~d}\right)^{\circ}$ ER. $^{\circ} \mathrm{As}^{\circ}$ is $^{\circ}$ common $^{\circ}$ with $^{\circ}$ MALDI analysis of unseparated digests, many potentially significant peptides were not observed. Nevertheless, the spectrum from untreated ER resulted in $42 \%$ sequence coverage when searched against the SwissProt database, peaks ascribed to predicted ER peptides being indicated with asterisks, including the abundant diagnostic ${ }^{\circ} \mathrm{ZnF} 2 \mathrm{~B}^{\circ}$ peptide $^{\circ}$ at ${ }^{\circ} \mathrm{m} / \mathrm{z} 1064.5^{\circ}$ (Figure $\left.{ }^{\circ} 6 \mathrm{a}\right) .^{\circ}$ Alkylation of ER by IAA produced both the mono- and doubly-alkylated conjugates of $\mathrm{ZnF} 2 \mathrm{~B}$ at $\mathrm{m} / \mathrm{z} 1122.6$ and 1180.6, ${ }^{\circ}$ respectively ${ }^{\circ}$ (Figure $\left.{ }^{\circ} 6 \mathrm{~b}\right) .{ }^{\circ} \mathrm{ER}^{\circ}{ }^{\circ}$ treatment ${ }^{\circ}$ with $^{\circ} \mathrm{BrB}$ 
Table 3. Combined LC-ESI-MS/MS data derived from $4+$ and $5+$ precursor ions for synthetic peptide $\mathrm{ZnF}$ singly arylated by BrB or K3. Calculated $\mathrm{M}_{\mathrm{r}}$ 's for modification at cysteine residues corresponding to Cys-237 and Cys-240 of ER $\alpha$ are compared with derived $\mathrm{M}_{\mathrm{r}}$ 's based on experimentally observed $m / z$ values and charge states $(\mathrm{z})$. ND = peak not detectable above noise level

\begin{tabular}{|c|c|c|c|c|c|c|}
\hline Ion type & Calc. $\mathrm{M}_{\mathrm{r}}$ & $\begin{array}{l}\text { Cys-237-BrB } \\
\text { obs. } m / z(z)\end{array}$ & Derived $M_{r}$ & Calc. $\mathrm{M}_{\mathrm{r}}$ & $\begin{array}{l}\text { Cys-240-BrB } \\
\text { obs. } m / z(z)\end{array}$ & Derived $M_{t}$ \\
\hline$y_{4}$ & 571.382 & $286.70(2)$ & 571.38 & 571.382 & $286.70(2)$ & 571.39 \\
\hline $\mathrm{y}_{4}-\mathrm{NH}_{3}$ & 554.365 & $278.18(2)$ & 554.34 & 554.365 & $278.19(2)$ & 554.37 \\
\hline$y_{5}$ & 674.401 & ND & ND & 864.475 & $433.23(2)$ & 864.48 \\
\hline $\mathrm{b}_{5}-\mathrm{NH}_{3}$ & 665.408 & $333.70(2)$ & 665.38 & 665.408 & $333.70(2)$ & 665.39 \\
\hline$y_{6}$ & 745.438 & ND & ND & 935.512 & $468.76(2)$ & 935.51 \\
\hline $\mathrm{Y}_{6}-\mathrm{NH}_{3}$ & 728.411 & ND & ND & 918.485 & $919.48(2)$ & 918.47 \\
\hline$y_{7}$ & 873.497 & ND & ND & 1063.571 & $532.81(2)$ & 1063.59 \\
\hline $\mathrm{y}_{7}-\mathrm{NH}_{3}$ & 856.470 & ND & ND & 1046.544 & $524.30(2)$ & 1046.59 \\
\hline $\mathrm{b}_{7}-\mathrm{H}_{2} \mathrm{O}$ & 1044.540 & ND & ND & 854.466 & $428.24(2)$ & 854.47 \\
\hline $\mathrm{y}_{13}-\mathrm{H}_{2} \mathrm{O}$ & 1789.946 & 1791.00 & 1790.00 & 1789.946 & $448.50(4)$ & 1789.99 \\
\hline \multirow[t]{2}{*}{$\mathrm{b}_{13}-\mathrm{NH}_{3}$} & 1772.911 & $444.23(4)$ & 1772.88 & 1772.911 & $444.23(4)$ & 1772.95 \\
\hline & & Cys-237-K3 & & & Cys-240-K3 & \\
\hline$y_{4}$ & 571.382 & $286.70(2)$ & 571.38 & 571.382 & $286.70(2)$ & 571.39 \\
\hline $\mathrm{y}_{4}-\mathrm{NH}_{3}$ & 554.365 & $278.18(2)$ & 554.34 & 554.365 & $278.19(2)$ & 554.37 \\
\hline$b_{5}-N_{3}$ & 665.408 & $333.70(2)$ & 665.38 & 665.408 & $333.70(2)$ & 665.39 \\
\hline$y_{6}$ & 746.438 & ND & ND & 915.475 & $458.72(2)$ & 915.48 \\
\hline$y_{7}$ & 873.497 & ND & ND & 1043.540 & $522.78(2)$ & 1043.56 \\
\hline $\mathrm{y}_{7}-\mathrm{NH}_{3}$ & 856.470 & ND & ND & 1026.507 & $514.78(2)$ & 1026.56 \\
\hline$b_{7}-\mathrm{H}_{2} \mathrm{O}$ & 1024.502 & ND & ND & 854.466 & $428.24(2)$ & 854.48 \\
\hline $\mathrm{b}_{10}-\mathrm{H}_{2} \mathrm{O}$ & 1326.607 & $663.35(2)$ & 1324.68 & 1326.607 & $663.35(2)$ & 1326.70 \\
\hline $\mathrm{y}_{13}-\mathrm{H}_{2} \mathrm{O}$ & 1769.904 & $443.49(2)$ & 884.96 & 1769.904 & $443.49(2)$ & 1769.96 \\
\hline$a_{13}$ & 1741.909 & 436.49 (4) & 1741.92 & 1741.909 & $436.49(4)$ & 1741.96 \\
\hline
\end{tabular}
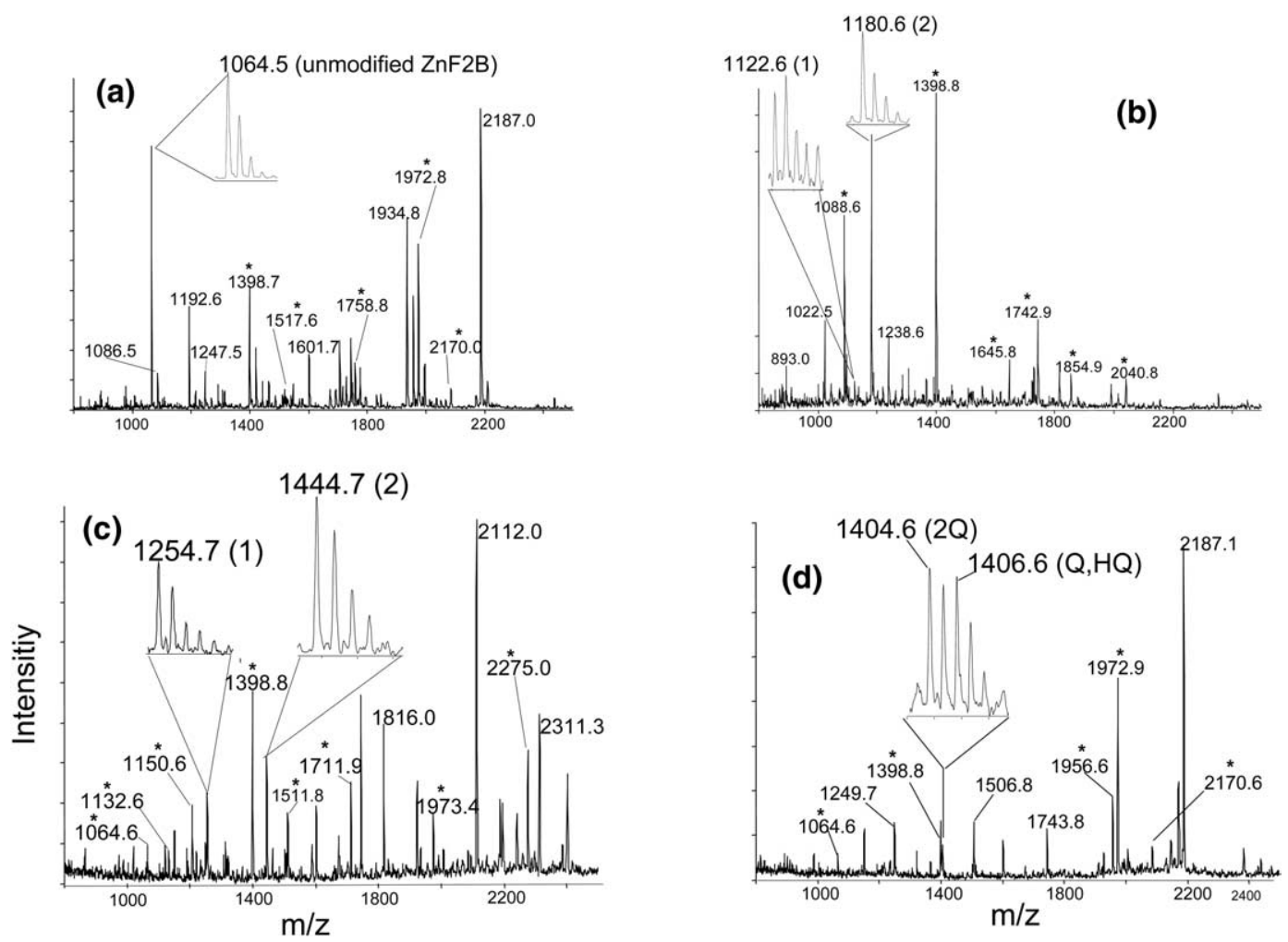

Figure 6. MALDI-TOF peptide mass fingerprints of Lys-C and Asp-N digested ER, either untreated or previously alkylated or arylated. (a) Untreated ER: $\mathrm{m} / \mathrm{z} 1064.5$ represents unmodified ZnF2B. (b) IAA-treated ER: $\mathrm{m} / \mathrm{z} 1122.6$ and 1180.6 represent mono (1) and doubly (2) alkylated ZnF2B. (c) BrB-treated ER: $m / z 1254.7$ and 1444.7 represent mono (1) and doubly (2) arylated ZnF2B. (d) K3-treated ER: $m / z 1404.6$ and 1406.6 represent doubly-arylated ZnF2B quinone (2Q) and quinone/ hydroquinone $(\mathrm{Q} / \mathrm{HQ})$. Peaks marked with asterisks correspond to other ER peptides. 


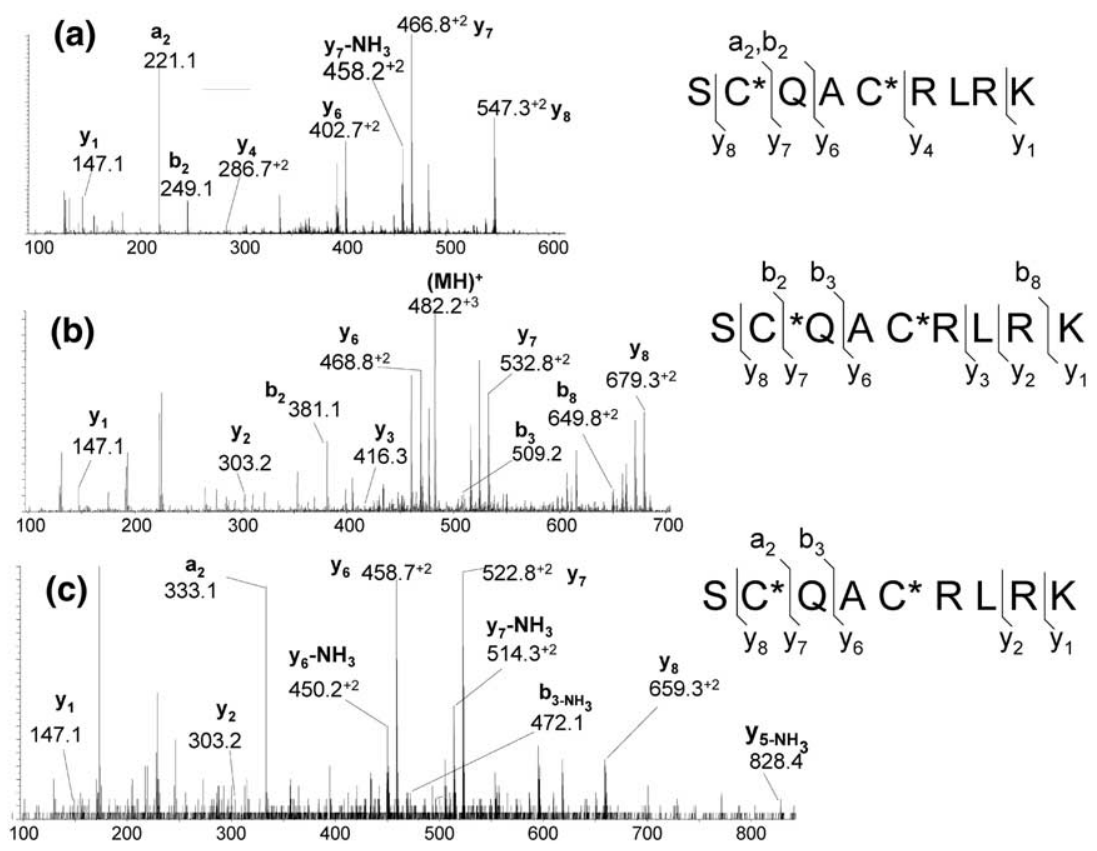

Figure 7. LC-ESI-MS/MS CID product ion mass spectra of doubly-conjugated ZnF2B triply-charged ions derived from in vitro chemical modification of ER followed by digestion with Lys-C and Asp-N: (a) Doubly IAA-alkylated ion of $\mathrm{m} / \mathrm{z}$ 394.2. (b) Doubly BrB-arylated ion of $\mathrm{m} / \mathrm{z}$ 482.2, (c) Doubly K3-arylated ion of $m / z 468.8$.

also produced mono- and doubly-alkylated conjugates of $\mathrm{ZnF2B}$, detected at $\mathrm{m} / \mathrm{z} 1254.6$ and 1444.7 , respectively ${ }^{\circ}$ (Figure $\left.{ }^{\circ} 6 \mathrm{c}\right){ }^{\circ}{ }^{\circ} \mathrm{In}^{\circ}$ contrast $^{\circ}{ }^{\circ} \mathrm{ER}^{\circ}$ treatment $^{\circ}$ with $^{\circ} \mathrm{K} 3$ produced only doubly-arylated adducts of $\mathrm{ZnF} 2 \mathrm{~B}$, corresponding to ions at $\mathrm{m} / \mathrm{z} 1404.6$ and 1406.6 , and representing the $\mathrm{Q}$ and $\mathrm{HQ}$ states of arylated $\mathrm{K} 3$, respectively (Figure ${ }^{\circ} \mathrm{d}$ ). ${ }^{\circ}{ }^{\circ}{ }^{\circ} \mathrm{a}^{\circ}$ separate $^{\circ}$ experiment, ${ }^{\circ} \mathrm{LC}$-ESI-MS ${ }^{\circ}$ analysis of the K3 treated sample demonstrated the existence of both the mono- and doubly-arylated conjugates of ZnF2B (data not shown).

As with the synthetic $\mathrm{ZnF}$ peptide substrate, the presence of unmodified ZnF2B peptide ions $(\mathrm{m} / \mathrm{z}$ 1064.6) in $^{\circ}$ the ${ }^{\circ}$ MALDI-TOF ${ }^{\circ}$ spectra ${ }^{\circ}$ shown ${ }^{\circ}{ }^{\circ}{ }^{\circ}$ Figure $^{\circ} 6 c^{\circ}$ and ${ }^{\circ} \mathrm{d}$ indicated that chemical modification of full-length ER by $\mathrm{BrB}$ and $\mathrm{K} 3$ was incomplete and generally proceeded at a slower rate than IAA alkylation. LC-ESI-MS/MS of the doubly-conjugated $\mathrm{ZnF} 2 \mathrm{~B}$ present in the same digests was performed to confirm that the modifications were specific to cysteine residues. In no treatment condition was there any fragment ions detected to suggest chemical conjugation to residues other than

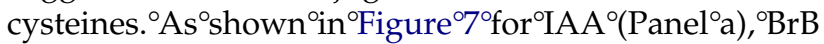
(Panel b), and K3 (Panel c) treatments, the observed Nand C-terminal fragment ions revealed conjugation to both Cys-237 and Cys-240. For example, compared with ZnF2B from unreacted ER (not shown), the reaction product from $\mathrm{BrB}$ produced an increase of $190 \mathrm{Da}$ between $y_{3} / y_{6}$ ions as well as $b_{2} / b_{3}$ and a characteristic increase of $380 \mathrm{Da}$ for the $\mathrm{b}_{8}$ and $\mathrm{y}_{8}$ fragment ions (Figure ${ }^{\circ} 7 \mathrm{~b}$ ). ${ }^{\circ}$ Similarly ${ }^{\circ}$ for ${ }^{\circ} \mathrm{K} 3$, a consistent increment of $170 \mathrm{Da}$ between $\mathrm{y}_{3} / \mathrm{y}_{6}$ and $\mathrm{a}_{2} / \mathrm{b}_{3}$ ions and $340 \mathrm{Da}$ between $\mathrm{y}_{7} / \mathrm{y}_{8}$ confirmed the presence of modifications to ${ }^{\circ}$ both $^{\circ}$ cysteine $^{\circ}$ residues $^{\circ}$ (Figure ${ }^{\circ} 7 \mathrm{c}$ ).

\section{Discussion}

Bromobimane fluorescence provides a sensitive tool for protein detection following modification of Cys thiol groups. Our results demonstrate that this fluorescence can also provide an overall picture of cysteine oxidation, as only those Cys residues having free thiols are accessible to react with BrB. However, fluorescence provides only a general picture, devoid of information about the status of individual cysteine residues. This is a particular problem in evaluating the oxidation status of the ER-DBD as only 8 of the 13 cysteine residues in ER play a role in zinc binding. Consequently, it was important to develop more specific methods to probe the sensitivity of individual cysteine thiols to covalent modifications produced by chemical agents capable of impairing ER DNA-binding function.

The strong nucleophilic character of the cysteine residue derives from thiol deprotonation to form the thiolate anion, the pKa of which may range from 6.0 to 8.5 , depending on the local charge environment of the cysteine ${ }^{\circ}$ residue $^{\circ}\left[23,{ }^{\circ} 24\right] .^{\circ}$ Thus, under more basic conditions, deprotonation of thiols to form thiolates is enhanced, consistent ${ }^{\circ}$ with $^{\circ}$ the ${ }^{\circ}$ enhanced ${ }^{\circ}$ alkylation ${ }^{\circ}$ rate of ${ }^{\circ}$ the ${ }^{\circ} \mathrm{ZnF}^{\circ}$ peptide ${ }^{\circ}$ to $\mathrm{IAA}^{\circ}$ and $^{\circ} \mathrm{BrB}^{\circ}\left(\right.$ Table $\left.^{\circ} 2\right) .^{\circ}$ The reaction ${ }^{\circ}$ of each cysteine thiolate with IAA or $\mathrm{BrB}$ typifies a bimolecular nucleophilic substitution reaction $\left(\mathrm{S}_{\mathrm{N}} 2\right)$. For such reactions that involve halogen leaving groups, the rate of reaction is affected to a large extent by the electronegativity of the leaving group as well as the bond strength between the halogen and the carbon atom of the alkyl/aryl group, giving rise to the following order of reactivity for the halides: $\mathrm{I}^{-}>\mathrm{Br}^{-}>\mathrm{Cl}^{-}$ 
$\gg \mathrm{F}^{-}$. This may partly contribute to the difference in reactivity (3.5-fold) observed between IAA and $\mathrm{BrB}$, although steric factors must also be taken into consideration. The bulkier BrB alkylator is expected to react more slowly than IAA.

Although $\mathrm{N}$-terminal and $\varepsilon$-amino groups may serve as potential targets in Michael addition reactions at $\mathrm{pH}$ $>8$, at physiological $\mathrm{pH}$ the Michael type reactivity of amines is almost an order of magnitude slower than thiols ${ }^{\circ}[25] .{ }^{\circ}$ These $^{\circ}$ previous $^{\circ}$ observations ${ }^{\circ}$ are $^{\circ}$ consistent with our present findings, showing that at physiological $\mathrm{pH}$, the primary Michael addition targets of $\mathrm{K} 3$ in $\mathrm{ZnF}$ are its cysteine residues. In contrast to the more rapid reactivity of the halogenated reagents under basic conditions, $\mathrm{K} 3$ addition occurred more rapidly under acidic

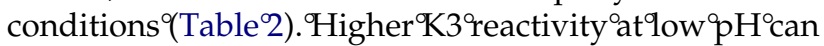
partly be explained by the availability of protons to interact (H-bond) with a negatively charged $\mathrm{K} 3$ carbonyl oxygen, effectively increasing the relative positive charge at the meta-position of the quinone and acceptor site of cysteine attack. Furthermore, under acidic conditions, the cysteine thiol is fully protonated and nucleophilic addition reaction is driven by the available electron pair on the sulphur atom. Consequently, the protonated thiol form of cysteine may serve as the preferred nucleophile relative to the thiolate that is the predominant species occurring under basic conditions. This is in contrast to previous reports which indicated that in Michael-type reactions, thiolates $\left(\mathrm{S}^{-}\right)$ rather than thiols $(\mathrm{SH})$ are the generally preferred nucleophiles ${ }^{\circ}$ [23-25]. ${ }^{\circ}$ However, ${ }^{\circ}$ our ${ }^{\circ}$ observed ${ }^{\circ} \mathrm{K} 3{ }^{\circ}$ reaction kinetics are consistent with an earlier study showing that protonated cysteine thiols are reactive to $\mathrm{Mi}$ chael acceptors having an $\alpha, \beta$ unsaturated carbonyl system, ${ }^{\circ}$ such $^{\circ}$ as $^{\circ} \mathrm{K} 3^{\circ}[26]$.

It is notable that MALDI-TOF was better able than LC-ESI-MS to discriminate between the $Q$ and HQ states of $\mathrm{K} 3$ conjugates on either $\mathrm{ZnF}$ or recombinant ER. Thus, an LC-ESI-based analysis is not appropriate for an accurate determination of the $\mathrm{HQ}: \mathrm{Q}$ conjugate ratios, even though such ratios may be biologically significant. From this point of view, MALDI would be the preferred choice for monitoring HQ:Q conjugates. Furthermore, tandem studies carried out by MALDITOF/TOF also proved to be effective for structural analysis of the peptides.

The present study also draws attention to the fact that the two cysteine thiols within $\mathrm{ZnF} 2 \mathrm{~B}$ are not chemically equivalent. Cys-240 is flanked on either side by Ala-239 and Arg-241, whereas Cys-237 is sandwiched between $^{\circ}$ Ser- $236^{\circ}$ and ${ }^{\circ} \mathrm{Gln}-238^{\circ}$ (Figure 1 ). ${ }^{\circ}$ Neighboring amino acids can determine thiol $\mathrm{pK}_{\mathrm{a}}$ and, thus, the chemical reactivity of an entire protein, as has been shown for the active enzymatic site of thioredoxin in which nearby Asp carboxyl and Lys amino groups influence local thiol $\mathrm{pK}_{\mathrm{a}}$ and thereby influence the rate of $^{\circ}$ thiol $^{\circ}$ disulfide $^{\circ}$ reactions $^{\circ}$ at $^{\circ}$ physiological $^{\circ} \mathrm{pH}^{\circ}$ [27]. Based on tandem-MS fragmentation experiments with mono-conjugated ZnF peptide, we observed that Cys-
240 is much more reactive than Cys-237. Unlike the first zinc finger of ER, which contains only three basic residues, the second zinc finger contains eight basic residues, ${ }^{\circ}$ all $^{\circ}$ in $^{\circ}$ its $^{\circ} \mathrm{C}$-terminal region ${ }^{\circ}\left(\right.$ Figure $\left.^{\circ} 1\right) .{ }^{\circ}$ Consequently, thiols within the second zinc finger would be expected to have lower $\mathrm{pK}_{\mathrm{a}}$ and to be more reactive than their counterparts in the first zinc finger, possibly contributing to the observed greater reactivity of the ER second zinc finger to $\mathrm{K} 3$ and other thiol targeting reagents. Based on this primary structure consideration, future studies might focus on specific cysteine residues other than those involved in zinc binding that are similarly flanked by basic residues (e.g., Cys-245, Cys530), as these might also be preferred targets for electrophilic attack.

\section{Conclusions}

As stated earlier, the primary goal of the present study was to develop and optimize a mass spectrometry based technique to fingerprint covalent changes occurring in the zinc fingers of human ER protein. The use of a model peptide with amino acid sequence that spans the C-terminal portion of the second zinc finger facilitated the development and optimization of effective mass spectrometric protocols. MALDI-TOF and LCESI-MS proved valuable for the detection and characterization of selected chemical modifications within the labile second zinc finger of full-length recombinant ER protein. The use of tandem-MS techniques allowed the specific locations of the chemical modifications to be identified, thus paving the way for an atomic understanding of how various oxidants actually deform ER. The results presented here confirm that basic amino acid residues can affect the $\mathrm{pK}_{\mathrm{a}}$ and, consequently, the reactivity of zinc finger thiols to electrophilic reagents. There are substantial difficulties in extrapolating in vitro studies on recombinant protein to the analysis of complex samples from human tissue. Nevertheless, it is anticipated that the resulting expertise that has been developed for characterizing potential chemical modifications to cysteine thiol groups in the ER-DBD will facilitate the cataloging of in vivo chemical modifications occurring in the endogenously overexpressed ER of human breast tumors.

\section{Acknowledgments}

This work was supported by NIH-sponsored grants R01-CA71468, R01-CA36773, R01-AG020521; California Breast Cancer Research Program grant CBCRP 10YB-0125; NCRR-RR01614 facility grant support to the UCSF Mass Spectrometry Facility (Director A. L. Burlingame); and generous donations to the Buck Institute by the Oracle Corporate Giving Program and the Hazel P. Munroe Memorial.

\section{References}

1. Moggs, J. G.; Orphanides, G. Estrogen receptors: Orchestrators of pleiotropic cellular responses. EMBO Rep. 2001, 2, 775-781. 
2. Pinzone, J. J.; Stevenson, H.; Strobl, J. S.; Berg, P. E. Molecular and cellular determinants of estrogen receptor alpha expression. Mol. Cell. Biol. 2004, 24, 4605-4612.

3. Liang, X.; Lu, B.; Scott, G. K.; Chang, C.-H.; Baldwin, M. A.; Benz, C. C. Oxidant stress impaired DNA-binding of estrogen receptor from human breast cancer. Mol. Cell. Endocrinol. 1998, 146, 151-161.

4. Baldwin, M. A.; Benz, C. C. Redox control of zinc finger proteins. Methods Enzymol. 2002, 353, 54-69.

5. Wang, L. H.; Yang, X. Y.; Zhang, X.; Mihalic, K.; Fan, Y. X.; Xiao, W.; Howard, O. M. Z.; Appella, E.; Maynard, A. T.; Farrar, W. L. Suppression of breast cancer by chemical modulation of vulnerable zinc fingers in estrogen receptor. Nat. Med. 2004, 10, 40-47.

6. Jung, J.; Ishida, K.; Nishihara, T. Anti-estrogenic activity of fifty chemicals evaluated by in vitro assays. Life Sci. 2004, 74, 3065-3074.

7. Maynard, A. T.; Covell, D. G. Reactivity of zinc finger cores: Analysis of protein packing and electrostatic screening. J. Am. Chem. Soc. 2001, 123, 1047-1058.

8. Schwabe, J. W.; Rhodes, D. Beyond zinc fingers: Steroid hormone receptors have a novel structural motif for DNA recognition. Trends Biochem. Sci. 1991, 18, 291-296.

9. Schwabe, J. W.; Neuhaus, D.; Rhodes, D. Solution structure of the DNA-binding domain of the estrogen receptor. Nature 1990, 348, 458-461.

10. Whittal, R. M.; Benz, C. C.; Scott, G.; Semyonov, J.; Burlingame, A. L.; Baldwin, M. A. Preferential oxidation of zinc finger 2 in estrogen receptor DNA-binding domain prevents dimerization and, hence, DNA binding. Biochemistry 2000, 39, 8406-8017.

11. Bolton, J. L. Quinoids, quinoid radicals, and phenoxyl radicals formed from estrogens and antiestrogens. Toxicology 2002, 177, $55-65$.

12. Cavalieri, E. L.; Rogan, E. G.; Chakravarti, D. Initiation of cancer and other diseases by catechol ortho-quinones: A unifying mechanism. Cell. Mol. Life Sci. 2002, 59, 665-681.

13. Liu, X.; Yao, J.; Pisha, E.; Yang, Y.; Hua, Y.; van Breemen, R. B.; Bolton, J. L. Oxidative DNA damage induced by equine estrogen metabolites: Role of estrogen receptor alpha. Chem. Res. Toxicol. 2002, 15, 512-519.

14. Russo, J.; Russo, I. H. Genotoxicity of steroidal estrogens. Trends Endocrinol. Metab. 2004, 15, 211-214.

15. Bolton, J. L.; Trush, M. A.; Penning, T. M.; Dryhurst, G.; Monks, T. J. Role of quinones in toxicology. Chem. Res. Toxicol. 2000, 13, 135-160.
16. Scott, G. K., Atsriku, C., Kaminker, P., Held, J., Gibson, B., Baldwin, M. A., Benz, C. C. Mol. Pharmacol. 2005, 68, 606-615.

17. Scozzafava, A.; Casini, A.; Supuran, C. T. Targeting cysteine residues of biomolecules: New approaches for the design of antiviral and anticancer drugs. Curr. Med. Chem. 2002, 9, 1167-1185.

18. Lame, M. W.; Jones, A. D.; Wilson, D. W.; Segall, H. J. Protein targets of 1,4-benzoquinone and 1,4-naphthoquinone in human bronchial epithelial cells. Proteomics 2003, 3, 479-495.

19. Meza, J. E.; Scott, G. K.; Benz, C. C.; Baldwin, M. A. Essential cysteine-alkylation strategies to monitor structurally altered estrogen receptor as found in oxidant-stressed breast cancers. Anal. Biochem. 2003, 320, 21-31.

20. Sechi, S.; Chait, B. T. Modification of cysteine residues by alkylation. A tool in peptide mapping and protein identification. Anal. Chem. 1998, 70, 5150-5158.

21. Kim, Y. J.; Pannell, L. K.; Sackett, D. L. Mass spectrometric measurement of differential reactivity of cysteine to localize protein-ligand binding sites. Application to tubulin-binding drugs. Anal. Biochem. 2004, 332, 376-383.

22. Kortemme, T.; Creighton, T. E. Ionization of cysteine residues at the termini of model $\alpha$-helical peptides. Relevance to unusual thiol $\mathrm{pKa}$ values in proteins of the thioredoxin family. J. Mol. Biol. 1995, 253, 799-812.

23. Lutolf, M. P.; Tirelli, N.; Cerritelli, S.; Cavalli, L.; Hubbell, J. A. Systematic modulation of Michael-type reactivity of thiols through the use of charged amino acids. Bioconjugate Chem. 2001, 12, 1051-1056.

24. Bednar, R. A. Reactivity and $\mathrm{pH}$ dependence of thiol conjugation to N-ethylmaleimide: Detection of a conformational change in chalcone isomerase. Biochemistry 1990, 29, 36843690.

25. Friedman, M.; Cavins, J. F.; Wall, J. S. Relative nucleophilic reactivities of amine groups and mercaptide ions in addition reactions with $\alpha, \beta$ unsaturated compounds. J. Am. Chem. Soc. 1965, 87, 3672-3682.

26. Gorin, G.; Martic, P. A.; Doughty, G. Kinetics of the reaction of $\mathrm{N}$-ethylmaleimide with cysteine and some congeners. Arch. Biochem. Biophys. 1966, 115, 593-597.

27. Dyson, H. J.; Jeng, M. F.; Tennant, L. L.; Slaby, I.; Lindell, M.; Cui, D. S.; Kuprin, S.; Holmgren, A. Effects of buried charged groups on cysteine thiol ionization and reactivity in Escherichia coli thioredoxin: Structural and functional characterization of mutants of Asp 26 and Lys 57. Biochemistry 1997, 36, 26222636. 